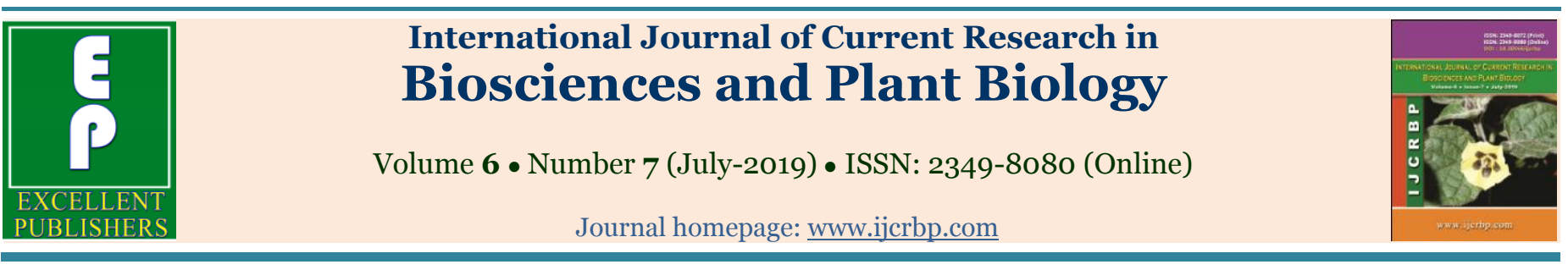

\title{
Physicochemical quality of ground water in Ogbomoso north local Government area of Oyo State, Nigeria
}

\author{
O. N. Oyewole* ${ }^{*}$ A. E. Falodun and J. G. Omosebi \\ Department of Science Technology, The Federal Polytechnic, Ado-Ekiti, Ekiti State, Nigeria \\ ${ }^{*}$ Corresponding author; e-mail: oyewoleoyewuminather@gmail.com
}

\begin{tabular}{|c|}
\hline Article Info \\
\hline $\begin{array}{l}\text { Date of Acceptance: } \\
\text { O2 June } 2019\end{array}$ \\
\hline $\begin{array}{l}\text { Date of Publication: } \\
\text { o6 July } 2019\end{array}$ \\
\hline Keywords \\
\hline $\begin{array}{l}\text { Domestic water } \\
\text { Ground water } \\
\text { Ogbomoso } \\
\text { Water quality }\end{array}$ \\
\hline
\end{tabular}

\begin{abstract}
A systematic study has been carried out with the aim to assess the ground water quality index of Hamama in Ogbomosho North Local Government area in Oyo State with a view to determine it suitability for domestic purpose. Water sample were collected from eight wells that were available within the study area in the rainy season of 2018 and were analysed for physicochemical parameters (colour, $\mathrm{pH}$, conductivity, total dissolved solid, hardness, sulphate, iron, chloride, zinc and lead content). Each parameter was compared with the standard desirable limit as prescribed by different agencies. The analytical data of various physicochemical parameters fall below the limits prescribed by NSDWQ and WHO. This means the water obtained from these study area are suitable for domestic usage.
\end{abstract}

\section{Introduction}

Water is a key component in determining the quality of our lives. Although water cover about 70 percent of the earth's total surface, only $0.3 \%$ of it can be used by human being (Tiimub et al., 2012). Among the various source of water of water, the ground water is the largest reservoir of the drinkable water..Ground water is that water found in saturated part of the ground underneath the land surface. It normally accumulate there when the water pore spaces found between soil particles and cracks in the rock. The water eventually reaches a depth where the soil and the rock are saturated (USEPA, 2014). Ground water is an important source of water supply with a number of advantages. Ground water is commonly free from pathogenic organism due to infiltration (and therefore requires little or no treatment). Despite these advantages, however ground water is susceptible to pollution as a result of past activities (Chapman, 1992). It is an important source of water for domestic uses especially in developing counties like Nigeria, due to long retention time and filtration capacity of aquifers. Water that is meant for domestic use is contaminated with pathogens, poisonous substances and excessive amount of mineral and organic matter.

Although water is an indispensable commodity for substance of life, there is however an which contained industrial, agricultural or domestic waste or even other occurring chemical in excess amount as to render the water unacceptable for its intended usage. Any substance that causes such undesirable changes in the water quality is known 
as pollutants. Assessment of the concentration of chemicals and other pollutants is ground water will help in ensuring sage water supply as a way of curtailing many direct threats to human health .Water is a chemical substance with chemical formula of $\mathrm{H}_{2} \mathrm{O}$ and is a liquid at room standard temperature and pressure.

Water is transparent in the visible electromagnetic spectrum. Thus aquatic plant can live in water because sunlight can reach them and the infra red light is strongly absorbed by the higher electronegativity than hydrogen atoms, it carries a slight negative charge, whereas the hydrogen atoms are slightly positive. As a result, water is a polar molecule with an electrical dipole moment.

The capillary action refers to the tendency of water to move up a narrow tube against the force of gravity. This property is relied upon by all vascular plants, such as trees (Anghem, 2010). Ground water refers to all water occupying the voids pores and fissures within geological formation, which originated from atmosphere precipitation either directly from the rivers, lakes or canal, sand, gravel sandstones and lime stones formation are the usual source of ground water supply though some may be drawn from impervious rocks such as when they have an over burden of sand or gravel. Ground water is a valued fresh resource and constituents about two-third of the fresh water reserves of the world (Buchanan, 1983). Ground water is used for agriculture, industrial and domestic purposes. It accounts for about 50\% of livestock and irrigation usage and just under $40 \%$ of water supplies, while in rural areas $98 \%$ of domestic water use is from ground water (Todd, 1980).

Ground water is abstracted through hand-dugs, hand-pump operated shallow wells and submersible pump operated deep well or boreholes(Ojo,2002). Ground water is often high in mineral content such as magnesium, calcium, iron and manganese depending on the chemical composition of the stratum through which the rock flows. Water hole was identified as the oldest means of obtaining surface water and this are classified into four types that demand full conventional treatment before use.

Wells and holes in the ground intersect the water table as the water bearing rocks flowing as aquifers
(Oluwande, 1983). Well water was divided into two namely shallow and deep wells depending on the location of impervious strata for which the water is obtained and also on the mode of construction. Well can be classified namely hand-dug well, bored well and driving well (Kotz et al., 2005). Shallow wells are generally less than $15 \mathrm{~m}$ deep while deep well are greater than50m in depth. They both exhibit differences in bacteriological quality and yield, with the water becoming purer and more constant with increase depth. Deep well are usually boreholes with depth above 100m and $150 \mathrm{~m}$ in diameter especially in the sedimentary formations. They serve large communities due to their high yield and it maintenance and rehabilitation are very important because of the tendencies for the well screen being clogged and corroded, thus reducing its effectiveness and efficiency.

Hand dug wells as the name implies are constructed manually and are little more than irregular hole in the ground, intersecting the water table. They are prone to pollution from airborne materials, run off from the surface, though their sanitary status may be improved by including certain features such as lining with cement ring or metal ring (Todd, 1980).

\section{Materials and methods}

Water samples were collected from eight hand dug wells that were available within Ogbomoso North Local Government area of Oyo State in the rainy season of 2018. Sterilized plastic containers were used for collecting water from the hand dug wells to avoid contact between the containers and the walls of the wells, thus avoiding contamination of the samples. Well labelled sterile bottles were used to collect the water sample and were tightly closed immediately. The samples were transported at low temperature to the laboratory for physicochemical analysis. The choice of water quality parameters for this investigation was based on WHO (1996) and NSDWQ (2004) guidelines. The physicochemical parameters investigated were electrical conductance, total dissolved solid, hardness, $\mathrm{pH}$, colour, chloride and iron. The $\mathrm{pH}$ and conductivity were measured directly using $\mathrm{pH}$ meter. The total dissolved solids calculated from conductivity values obtained. The sulphate, chloride and the iron contents were calorimetrically analysed using calorimeter. 


\section{Results and discussion}

The results of the physicochemical parameters of the water quality obtained in the course of this investigation are as presented in Tables 1- 2. The results show that the quality of water varies considerably from location to location along the stretch of Ogbomoso north local Government.
The $\mathrm{pH}$ of the study area was slightly acidic for sample B, C, E and F, but slightly alkaline for sample $\mathrm{A}, \mathrm{D}$ and $\mathrm{G}$. It ranged from 7.08 to 8.35 . The $\mathrm{pH}$ influences the taste and odour of the water significantly. Colour; Colour in drinking water arises from the presence of coloured organic substance which originate from decay of vegetable in surface water. All the water samples were colourless.

Table 1. The values of physicochemical characteristics of the underground water obtained from Hamama area in Ogbomosho north LGA of Oyo State metropolis.

\begin{tabular}{llllllll}
\hline Sample & $\begin{array}{l}\text { Conductivity } \\
(\boldsymbol{\mu S} / \mathbf{c m})\end{array}$ & $\begin{array}{l}\text { Total } \\
\text { dissolved } \\
\text { solid (ppm) }\end{array}$ & $\begin{array}{l}\text { Hardness } \\
(\mathbf{m g} / \mathbf{l})\end{array}$ & $\mathbf{p H}$ & $\begin{array}{l}\text { Sulphate } \\
(\mathbf{m g} / \mathbf{l})\end{array}$ & $\begin{array}{l}\text { Chloride } \\
(\mathbf{m g} / \mathbf{l})\end{array}$ & $\begin{array}{l}\text { Iron } \\
(\mathbf{m g} / \mathbf{l})\end{array}$ \\
\hline $\mathrm{A}$ & 106 & 47.70 & 20.70 & 7.11 & 12 & 7.10 & 0.10 \\
$\mathrm{~B}$ & 151 & 67.95 & 17.40 & 6.86 & 10 & 7.10 & 0.20 \\
$\mathrm{C}$ & 134 & 60.30 & 23.60 & 6.87 & 16 & 5.33 & 0.20 \\
$\mathrm{D}$ & 181 & 81.45 & 28.70 & 7.08 & 12 & 8.88 & 0.20 \\
$\mathrm{E}$ & 236 & 106.20 & 40.10 & 6.98 & 12 & 7.10 & 0.10 \\
F & 190 & 85.50 & 22.30 & 6.88 & 18 & 10.65 & 0.10 \\
G & 138 & 62.10 & 24.10 & 7.11 & 22 & 8.88 & 0.10 \\
WHO & 100 & 1500 & - & $7.0-8.5$ & 200 & 200 & 0.30 \\
Standard & & & & & & & 0.30 \\
NSDWQ & 1000 & 500 & 150 & - & 200 & 250 & 0 \\
\hline
\end{tabular}

Conductivity: This is the ability of water to conduct electric current and this is mostly influenced by dissolved salts such as sodium chloride and potassium chloride. All the water samples have conductance values which fall within the recommended limits of 1000 set by NSDWQ and WHO.

TDS: This parameter arises from organic origin as well as decomposition of inorganic substances. From the result obtained, the TDS values ranges from 47.70 to 106.20 and all the sample did not exceed the limit set by WHO.

Total Hardness: This is the sum of calcium and magnesium concentration in $\mathrm{mg} / \mathrm{L}$. It is the degree of capacity of water to precipitate the soap. The values of total hardness recorded in all the samples ranged from 17.40 to 40.10 . But no specific values were mentioned by WHO as the threshold limit for total hardness. However, if the value set by NSDWQ is considered, the total hardness in water collected from all the locations fall far below the limit of $150 \mathrm{mg} / \mathrm{L}$ recommended by the regulatory body. This implies that the form of hard scales on household cooking utensil and any similar metallic objects when subjected to heat. The heavy metals considered in the course of this investigation were zinc, iron, chloride and lead (Table 2). With the exception of lead all the heavy metals investigated in the course of this work was detected in the water samples analysed. The mean concentration of the detected metals fall below the critical limit set by NSDWQ and WHO.

Total Iron: Iron is normally present in underground water in the soluble form of $\mathrm{Fe}^{2+}$ which is easily oxidized to insoluble form of $\mathrm{Fe}^{3+}$. Underground water normally contained the soluble form of $\mathrm{Fe}^{2+}$, due to in sufficient supply of oxygen in the ground aquifer. The entire sample contained iron in concentration range from 0.1 to 0.2 which falls within the acceptable limits of 0.30 recommended by NSDWQ and WHO.

Sulphate: The result of this investigation revealed that the sulphate concentrations range from 12 $\mathrm{mg} / \mathrm{L}$ to $18 \mathrm{mg} / \mathrm{L}$ were detected in water samples obtained from the hang dug wells and compiled with the limits of $200 \mathrm{mg} / \mathrm{L}$ recommended by both NSDWQ and WHO.

Chloride: This is usually in form of chloride of metals, The concentrations of chloride in all the sample ranged from $5.33 \mathrm{mg} / \mathrm{L}$ to $10.65 \mathrm{mg} / \mathrm{L}$ which probably fall within the limits of $250 \mathrm{mg} / \mathrm{L}$ or $200 \mathrm{mg} / \mathrm{L}$ set by NSDWQ and WHO respectively. 
Table 2. The mean concentration of metals in water samples.

\begin{tabular}{lllllllll}
\hline Parameter & $\mathbf{1}$ & $\mathbf{2}$ & $\mathbf{3}$ & $\mathbf{4}$ & $\mathbf{5}$ & $\mathbf{6}$ & NSDWQ & WHO \\
\hline Zinc & 0.25 & 0.26 & 0.21 & 0.24 & 0.22 & 0.25 & $5 \mathrm{mg}$ & $5 \mathrm{mg} / \mathrm{L}$ \\
Iron & O.02 & O.20 & O.11 & 0.10 & 0.20 & 0.10 & 0.3 & 0.30 \\
Lead & ND & ND & ND & ND & ND & ND & 0.5 & $1-1.5$ \\
\hline
\end{tabular}

\section{Conclusion}

From the present investigations, it is concluded that the quality of all the water samples under study was suitable for drinking purpose in all the season.

\section{Conflict of interest statement}

Authors declare that they have no conflict of interest.

\section{References}

Anghem, K., 2000. Drinking water, treatment agents and health. J. Royal Soc. Health 2(99), 151-159.

Bruchanan, 1983). Ground water quality and quantity assessment. J. Ground Water pp.93200

Chapman, M., 1992. Water Quality Assessments. Chapman and Hall Ltd. WHO, UNEP, UNESCO, Churchil Living Stone, Edinburgh,
London and New York, pp.484-488.

Kotz, J. C., Treichel, P. M., Weaver, G. C., 2005. Chemistry and Chemical Reactivity. $6^{\text {th }}$ Edn. Brooks Cole Publn.

Ohuwande, P., 1983. Guide to Tropical Environmental Health Engineering Nigerian Institute of Social and Economic Research Ibadan (NISER), Ibadan. pp.141-147.

Ojo, O. I., 2002. Construction and Maintenance of Bore hole in Anambra State (Ptf Sponsored Project Experience). M.Sc. Seminar Report, Department of Agricultural and Environmental Engineering, University of Ibadan.

Tiimub, B. M., Kuffour, R. A., Akwanta, G. A., 2012. Quality determination of ground water for drinking at Nkawkaw in the eastern region of Ghana. Civil Environ. Res. 2(9), 49-62.

Todd, K., 1980. Ground Water Hydrology. $2^{\text {nd }}$ Edn. John Wiley \& Sons, New York, Chichester.

USEPA, 2004. The Water Cycle and Water Conservation. http://www.epa.gov/region /students/pdfs/gndw 712pdf.

\section{How to cite this article:}

Oyewole, O. N., Falodun, A. E., Omosebi, J. G., 2019. Physicochemical quality of ground water in Ogbomoso north local Government area of Oyo State, Nigeria. Int. J. Curr. Res. Biosci. Plant Biol. 6(7), 1417. doi: https://doi.org/10.20546/ijcrbp.2019.607.002 